\title{
METHODOLOGICAL BASES OF PUBLIC ADMINISTRATION OF PUBLIC DEVELOPMENT IN UKRAINE
}

\author{
Kyrylo OHDANSKYI, \\ Dnipropetrovsk Regional Institute of Public Administration, \\ National Academy of Public Administration under the President of Ukraine
}

\begin{abstract}
An author in the article examines theoretical bases in the question of dynamics of community development. According to classic canons a dynamic process on any of levels of management hierarchy can be presented as a complex of changes of its ecological, economic and social components. For today, national politics in the field of realization of conception of community development does not take into account most theoretical works, which testify that in our country the mechanism of its effective adjusting is not yet created. In connection to this the author of the article accents the attention on the necessity of the use in modern Ukraine realities of the effective approaches to government control of community development. As the subject of research of the article the author chose the analysis of process of community development and methodological bases for the choice of variants for a management by this process. System approach is chosen by author as a research methodology. The aim. Analysis of theoretical bases and developing of the new approaches to the government administration of community development. An author divides the process of community development by constituents: social, economic and ecological components. From the indicated warning it is necessary to take into account the objective necessity of developing of the new conceptual approaches to the elaboration of tool of adjusting of community development. For the decision of this task the author of the article it is suggested to use the category "dynamics". An author in the article does the analysis of different interpretations of term "dynamics"and offers his own interpretation in the context of community development. Our researches confirm that, mainly, it is methodologically possible to form the blocks of quantitative and quality factors of specific different information of ecological, economic and social character. Author's researches confirm that it is methodologically possible to form the blocks of quantitative and quality factors containing specific different information of ecological, economic and social character. It is useful to apply for the simplification of process of analysis of community development and for the choice of instruments for his adjusting. Author is predisposed to that the amount of constituents in every block must be varied depending on the depth of research. An optimal amount in a range 7-11 indicators in every block is offered by the author. The obtained system will have a subjective estimation and can be used only for the decision of the concrete assigned tasks. In case of changing of accents and aims of government control of community development the structure of these blocks must be reoriented. If to talk about possibility of creation or modeling of the universal system of blocks, then her using as a standard is possible only in the developed countries, and also in case of absence of indexes for comparison. Conclusion. The author argues in the article, that the primary concern of government regulation of community development is a necessity of clear determination of orientation of development. The special attention is given to the question of study of instruments of adjusting of community development. The author makes an accent on the necessity of application of the offered developments in practice for the quality monitoring and estimation of level of community development.
\end{abstract}

Key words: public development, dynamics, methodology, tools, integrated model.

JEL Classification: 115, B41, C81, C65

Corresponding author:

${ }^{1}$ Management Faculty, Dnipropetrovsk Regional Institute of Public Administration,

National Academy of Public Administration under the President of Ukraine

E-mail: ogdankn@gmail.com 


\section{Introduction}

In the early 90-ies of the twentieth century, Ukraine declared its aspiration to ensure sustainable development. The term "sustainable development", proposed by the UNO Conference on the natural environment and development in 1992, in its essence comes to maintain the specifics of social changes, "... to satisfy the needs of nowadays but not to endanger the ability of future generations to meet their own needs" (The program of actions «Agenda for the 21st century», 2000). According to this fact, the structure of sustainable development is formed by such components as economic, social and environmental. The economic peculiarity of implementation of "sustainable development" deals with resource saving, the social one focuses on the preservation of the stability of social systems through the equitable distribution of welfare, and environmental peculiarity deals with maintenance of abilities to self-recovery. It is important that all three elements of sustainable development should be considered and implemented simultaneously and balanced.

However, the national field of implementation of the concept of sustainable development does not confirm the statements of the theoretical notions by the empiric experience. In this context, the modern realities as to sustainable development indicate that in our country a mechanism for its ruled dynamics has not been created yet. Moreover, in Ukraine according to the use of the concept of "sustainable development" to refer to the steady growth of economic indicators its implementation is not confirmed even by longterm predictions. So, according to calculations done by the scientists of the State University of the Institute of Economic Forecasting of the National Academy of Sciences of Ukraine the changes of the indicator of the GDP per capita of population close to 2050 will be so small that Ukraine will remain the low places in the world rankings (Hejets, 2003).

\section{Analysis of recent research and publications}

This prospect requires a search for ways of creating conditions and development of toolkits to ensure sustainable development. In the context of this requirement there is a need to emphasize such rather important fact as attraction of national scientific community to solve sustainable development challenges practically simultaneously with foreign experts. Ukraine is not in luck to move in the way of scientific developments on this problem and it really was and remains on the edge of the scientific thought achievements. Issues of sustainable development were studied by such leading Ukrainian scientists as O. Bilorus (Bilorus, 2005), Z. Herasymchuk (Herasymchuk, 2008), M. Zgurovsky (Zgurovskiy, 2009), B. Danylyshyn (Danylyshyn, 1999), L. Maslovska (Maslovska, 2003), L. Melnyk (Melnyk, 2005), M. Hvesyk (Hvesyk, 2012) and others.

\section{Previously unsettled problem constituent}

The point is that developed and offered to use diagnostics methods of components of sustainable development are based on the concept of the static character. Meanwhile, the emergence of the term sustainable development is conditioned by the changes in the characteristics of its components within certain ranges, which require attracting the theory of dynamics. The system formation that sustainable development is, has its beginning and end, develops within a specific space and time. It should be stated that this essentially defined methodological aspect has been out of scientific investigations. Famous Ukrainian scientists and statesmen V. Semenozhenko and V. Hejets emphasized as regards this "... one of the key problems of Ukrainian strategic documents is incomprehension of the dynamics, changeability ... Almost in every document the changes that are taking place are not taken into account..." (Semynozhenko, 2008).

\section{Main purpose of the article}

However, despite the existence of a spectrum of scientific developments, the empirical realities do not confirm the decision of all problems related to the theoretical and methodological support of sustainable development. Moreover, according to the generalization of the new reality the position, under which its modern explanation is impossible on the basis of created conceptual and instrumental apparatus, is distinguished. Because of the mentioned warnings should be taken into consideration the objective necessity to develop new conceptual principles of informational and tool providing and controlling sustainable development based on the dynamic approach arises.

\section{Results and discussions}

Existing scientific heritage that has the interpretation of the term "dynamics" and to a certain extent, according to the stages of social promotion to civilized life, reveals its nature and adsorbs a variety of definitions of the diversified nature. Summing up of the conceptual views on the essence of the notion "dynamics" allowed qualifying it as an aimed in space and time process, described by the quantitative and qualitative characteristics. According to the classical canons the dynamic process on any of the hierarchical levels of management can be represented as a complex of changes of its environmental, economic and social spheres.

The availability in the socio-economic processes all components of dynamics allows providing the socioecological-economic dynamics with the concept of such nature: it is a process of a continuous targeted change of social, ecological and economic parameters in interaction and interdependence with appropriate domination of one of them and movement in the direction of civilization progression. Actually, the socio-ecological-economic 
dynamics is the cumulative trajectory that the society moves. Such understanding of social dynamics will allow formulating strategy and tactics of reformation transformations more carefully.

Given arguments as to the possibility of implementation of the economic system "theory of dynamics" provide an opportunity to outline the concepts "economic dynamics", "social dynamics", "environmental dynamics", as local processes of parameters changes of economic systems in time and space in the appropriate direction.

In our opinion, the economic dynamics should be associated with the process of natural changes of the quantitative and qualitative parameters of the economic subsystems in time and space, aimed to achieve a certain aggregate result.

As to the social dynamics, it is as a quantitative and qualitative, space and time, evolutionary process of natural changes of the potential of socialization and improvement of welfare of population.

Environmental dynamics is also a process in space and time with the quantitative and qualitative changes in logical and evolutionary character, but connected with the force of pressure of economic activity on the environment.

It should be noted that a systematic coherent socioecological-economic model on the conceptual apparatus has not been formed recently. Although such attempts have been made but there are not differentiation of the quantitative and qualitative factors of influence (Valenkevych, 2012).

Our investigations confirm that, in the main, methodologically it is possible to form blocks of the quantitative and qualitative factors of specific various information of environmental, economic and social nature. Based on the postulate of the adjective of "quantitative ", as some number whether quantity of anything, or "qualitative", as specific certainty of the subject, we make selection of informational and analytical characteristics that are under statistical accounting and allow expressing a greater number of signs through the least possible number of parameters. The quite important is the issue of the number of variables, by which one or another component of social dynamics has to be described. The experts for the operational assessment of a controlling measure of any process recommend limiting characteristics to 7-11 (Gusarov, 2003).

But for the real ruled public dynamics the determination of the factor filling of its constituents is not enough. To solve the issues in the administrative context the models, which can synthesize quantitative and qualitative achievements within their limits, in particular, and in total, are necessary? The complexity of their construction is in application of this methodology that would allow reproducing factor influences of different measures in the general indicators. To form assessment models of the cumulative dynamic progress and its constituents we used the tested instruments of bringing the various indicators to the comparative form through indexes. The calculation of indices is the process of comparing actual figures with the standard. Building the perfect object carries definitely subjective evaluation of the load. We, in particular, in the process of reasoning of one or another standard preferred only to the developed countries, and in the case of absence of indicators for comparison, carried out the optimization calculations.

\section{Conclusions and further researches directions}

Based on these standards and recommendations, we have calculated the indexes on all sets of factors of constituents of the socio-ecological-economic dynamics and for their explication qualification zones of their controlling were outlined. Of course, the point is to diagnose long-term trends that carry the applied load that is important to understand the quantitative-qualitative interdependence of production, processes of socialization and greening.

We have no reason to affirm that introduction in practice the analytical management activity of developed methodological bases simultaneously eliminates all the problems and provides the processes of social civilization promotion with clear directional character. The question is the opening by them the new tool and organizational possibilities to make balanced managerial decisions to ensure the social dynamics. Their potential to make quick administrative actions under the indicators that provide signals on the rollback of this or that zone handling by public promotion will contribute to the enhancement of the effectiveness of management of social dynamics. From the new paradigm standpoint the monitoring and evaluation of socio-economic-environmental dynamics, which focuses on and takes into account the complex of changes of parameters of ecological growth and ecological development, testing its main principles should be continued and the potential ability of combination of the purely analytical capabilities and improvement of the management system should be implemented then.

\section{References}

Bilorus, O.G. (2005). Global perspective and sustainable development. - K.: IAPM, 492 p.

Valenkevych, V.P. (2012). Argumentations of evaluation of socio-ecological-economic development of an administrative and territorial unit. A mechanism of economic regulation, № 3, p. 16-25.

Herasymchuk, Z.V. (2008). Regional policy for sustainable development: theory, methodology, practice: monograph. - Lutsk: Nadstir'ya, 528 p.

Gusarov, Y.V. (2003). Management: dynamics of non-equilibrium: scientific edition. - M.: Ecomonics, 382 p. 
Danylyshyn, B.M. (1999). Sustainable development in the system of natural and resources limitations. - K.: SOPS of Ukraine NAofSs, 367 p.

Hejets, V.M. (2003). Ukraine's economy: strategy and long-term development policy. - K.: IEF NAofSs of Ukraine; Feniks, 1008 p.

Maslovska, L.Ts. (2003). Sustainable development of the productive forces of regions: theory, methodology, practice: monograph. - K.: KNEU, 365 p.

Melnyk, L.G. (2005). Metodology of development: monograph. - Sumy: Universytetska knyga, 602 p.

The program of actions "Agenda for the 21st century": adopted by the UNO Conference on environment and development in Rio-de-Janeiro. (2000). - K.: Intelsfera, 360 p.

Semynozhenko, V. (2008). Ukraine - 2015: not to lose future. Day, 24 January, 16 p.

Zgurovskiy, M.Z. (2009). Sustainable development of the regions of Ukraine. - K.: NTUU "KPI", 197 p.

Hvesyk, M. (2012). National paradigm for sustainable development of Ukraine. Sustainable development, № 4, p. 5-10.

\section{Кирилл ОГДАНСКИЙ}

\section{МЕТОДОЛОГИЧЕСКИЕ ОСНОВЫ ОБЩЕСТВЕННОГО УПРАВЛЕНИЯ ОБЩЕСТВЕННЫМ} РАЗВИТИЕМ В УКРАИНЕ

Аннотация. Автор в своей статье рассматривает теоретические основы в вопросе динамики общественного развития. Согласно классическим канонам динамический процесс на любом из уровней иерархии управления может быть представлен в виде комплекса изменений его экологических, экономических и социальных компонентов. На сегодня, национальная политика в сфере реализации концепции общественного развития не учитывает большинства теоретических наработок, что свидетельствуют о том, что в нашей стране механизм ее эффективного регулирования еще не создан. В связи с этим автор статьи акцентирует свое внимание на необходимости использования в современных реалиях Украины эффективных подходов к государственному регулированию общественного развития. Предметом исследования статьи автор выбрал анализ процесса общественного развития и методологические основы для выбора вариантов для управления этим процессом. Методологией исследования автором выбран системный подход. Цель. Анализ теоретических основ и разработка новых подходов к государственному управлению общественного развития. Автор делит процесс общественного развития на составляющие: социальный, экономический и экологический компоненты. Из-за указанных предупреждений следует принимать во внимание объективную необходимость разработки новых концептуальных подходов к разработке инструментария регулирования общественного развития. Для решения данной задачи автором статьи предложено использовать категорию «динамика». Автор в статье делает анализ разных толкований термина «динамика» и предлагает свое толкование в контексте общественного развития. Наши исследования подтверждают, что, в основном, методологически можно образовывать блоки количественных и качественных факторов специфической различной информации экологического, экономического и социального характера. Исследования автора подтверждают, что методологически можно образовывать блоки количественных и качественных факторов содержащих специфическую различную информацию экологического, экономического и социального характера. Это удобно применять для упрощения процесса анализа общественного развития и выбора инструментов для его регулирования. Автор склоняется к тому, что количество составляющих в каждом блоке должно варьироваться в зависимости от глубины исследования. Автором предложено оптимальное количество в диапазоне 7-11 индикаторов в каждом блоке. Полученная система будет иметь субъективную оценку и может быть использована только для решения конкретных поставленных задач. При изменении акцентов и целей государственного регулирования общественного развития структура этих блоков должна быть переориентирована. Если говорить о возможности создания или моделирования универсальной системы блоков, то ее использование в качестве стандарта возможно только в развитых странах, а также в случае отсутствия показателей для сравнения. Вывод. Автор в своей статье аргументирует, что первоочередной задачей государственного регулирования общественного развития является необходимость четкого определения направленности развития. Особое внимание уделяется вопросу изучения инструментов регулирования общественного развития. Автор делает акцент на необходимости применения предложенных разработок на практике для качественного мониторинга и оценки уровня общественного развития. 